\title{
DELEUZE, FOUCAULT E O TRABALHO COM DOCUMENTOS
}

\author{
Flávia Cristina Silveira Lemos ${ }^{1}$ \\ Leandro Passarinho dos Reis Júnior ${ }^{2}$
}

\section{Introdução}

O campo discursivo de relações é tecido imanente ao não discursivo, sendo que o enunciado poderia ser repetido, pois é materializado em práticas de distribuição, "repartição de singularidades, a mesma ordem de locais e de posições, a mesma relação com um meio instituído" (DELEUZE, 2005, p. 22). Porém, o que é repetido pelo enunciado não é a mesma coisa já que há emissões de singularidades em sujeitos e com lugares vazios.

Assim, que o enunciado não pertence a um sujeito, se trata de um murmúrio anônimo. Ora, quando Foucault colocou em xeque os documentos e nossa relação com eles, marcou sua analítica de um monumento arquivo, neste sentido que postulou que os enunciados são diferentes das palavras, das proposições e das frases. Os enunciados são uma função de existência e a unidade mais elementar de um discurso, de acordo com Foucault (2009).

O arquivo é o espaço correlativo que se relaciona com "sujeitos, seus objetos, seus conceitos" (DELEUZE, 2005, p. 18). Assim, "um mesmo enunciado pode ter várias posições, vários lugares de sujeito" (DELEUZE, 2005, p. 19). Haveria um objeto discursivo, para Foucault e não um referente ou intencionalidade. Os enunciados possuem conceitos, esquemas discursivos. Desse modo, "o espaço correlativo é a ordem discursiva dos lugares ou posições dos sujeitos, dos objetos e dos conceitos numa família de enunciados." (DELEUZE, 2005, p. 20-1).

Além do espaço colateral e do correlativo, Foucault teria postulado "o espaço complementar ou de formações não discursivas (instituições, acontecimentos políticos, práticas e processos econômicos)" (DELEUZE, 2005, p. 21). Ora, se há enunciados nas instituições os mesmos também se referem concomitantemente às instituições, o que implica em configuração de objetos e constituição de posições de sujeitos. Em uma análise, produzimos uma dispersão entre as diversas práticas que construíram os dispositivos de proteção da criança e do adolescente, a partir das emergências dos objetos infância e adolescência, problematizando-os enquanto efeitos de práticas de objetivação.

O trabalho do genealogista é demorar-se sobre os documentos como monumentos que narram o cotidiano, os detalhes banais, o que parece não ter história e realizar uma descrição e análise paciente, minuciosa. "O objeto se explica pelo que foi o fazer em cada momento da história" (VEYNE, 1998, p. 257). O que se problematiza são as práticas de ver e de dizer, de acordo com Deleuze (2005); nesse caso, instituições são práticas e não totalidades fechadas que operam como mecanismos.

De acordo com Foucault (1979, p. 244), a genealogia entra em cena pelo campo de forças, dinâmicas e móveis, exercidas pela formação de um diagrama enquanto um dispositivo, ou seja, conforme "um conjunto decididamente heterogêneo que engloba discursos, instituições, organizações arquitetônicas, decisões regulamentares, leis, medidas administrativas, enunciados científicos, proposições filosóficas, morais, filantrópicas”.

\footnotetext{
${ }^{1}$ Professora do Programa de Pós-Graduação de Psicologia Social da Universidade Federal do Pará. E-mail: flavialemos@ufpa.br

${ }^{2}$ Bacharel e Licenciado em Psicologia, Licenciado em Pedagogia, Letras e Ciências Biológicas. Doutor em Educação pela Universidade Federal do Pará.
} 
O dispositivo pode qualificar algumas falas, desautorizando outras; conservando alguns discursos em arquivos e banindo outros, distribuindo alguns discursos e impedindo a circulação de outros, definindo fronteiras de discursos em disciplinas específicas, produzindo veneração de determinados discursos, recortando-os e os recompondo em novas roupagens. Analisar os fatos de discurso no elemento geral de arquivo é considerá-los não absolutamente como documentos (de uma significação escondida ou de uma regra de construção), mas como monumentos [...] (FOUCAULT, 2005, p. 95).

“[...] Entre o poder e o saber, há diferença de natureza, heterogeneidade; mas há também pressuposição recíproca e capturas mútuas e há, enfim, primado de um sobre o outro [...]" (DELEUZE, 2005, p. 81). Nesse sentido, procuramos marcar os traçados das lutas, tensionando os consensos que visam silenciar as vozes dissonantes e aplacar a coragem da verdade, sem temer os riscos desta experimentação. Por isto, que toda a filosofia de Foucault é uma pragmática do múltiplo (DELEUZE, 2005).

Fazer uma pragmática, conforme assinala Veyne (1998) é descrever as práticas como o que é feito, como história problema do que foi feito por nós, concretamente e materialmente, sem causalidade e sem finalidade; que, por sua vez têm correlatos, referentes; ou seja, eles se referem a um tema, em um espaço de correlação. Ainda vale mencionar a ligação dos enunciados com as condições de emergência dos objetos, em termos das possibilidades de aparecimento e de limitação. Os enunciados têm suportes, lugares e datas, podem ser repetidos; todavia, a enunciação não se repete (FOUCAULT, 2009).

Os discursos são um conjunto de enunciados organizados em um sistema de formação discursiva, em que a análise não deverá ser interpretativa, nem partir das deduções lineares, mas das posições dos sujeitos, da formação dos objetos, das modalidades enunciativas, dos lugares institucionais, dos lugares estratégicos, da formação dos conceitos e dos temas (FOUCAULT, 2004).

\section{Considerações finais}

O arqueólogo não busca conceitos gerais e abstratos e sim os analisa em um jogo de aparição e deslocamento. Um objetivo fundamental na pesquisa com arquivos é demarcar quais seriam as correlações entre os temas e as transformações ocorridas é importante bem como levantar o espaço comum entre os conceitos e os temas que foram relacionados. Há uma exterioridade do discurso e não uma lógica interna baseada em intencionalidades.

As práticas são um posicionamento de certo estatuto, um lugar de onde se fala, portanto, um campo genealógico de poder, o qual está articulado aos lugares institucionais ocupados. Já, as modalidades enunciativas estão vinculadas às ordens do discurso em termos de comentário, sociedades do discurso e doutrinárias etc. Para Foucault (2004), analisar o princípio do comentário é importante para efetuar uma ontologia crítica de nós mesmos, pois a repetição de enunciados funciona pela lógica de um conjunto de autores hierarquizados pelos controles discursivos.

Outro ponto relevante é a interrogação da formação das disciplinas e como essa organização dos saberes de forma disciplinar visa criar uma ideia de unidade discursiva para o que de fato é disperso. Ainda vale observa a tática apresentada por Foucault (2004) da interrogação dos controles exercidos pelas sociedades doutrinárias e pelas sociedades do discurso dogmáticas. Ambas, selecionam alguns discursos e interditam outros, em um jogo permanente e de coexistência de linhas entrecruzadas.

Analisar a produção dos arquivos como suportes de guarda de um conjunto de documentos montado e selecionado, criado e conservado implica interrogar sobre a constituição dos mesmos, os discursos que trazem e as relações de poder que ensejam. 


\section{DELEUZE, FOUCAULT E O TRABALHO COM DOCUMENTOS}

\section{Referências}

DELEUZE, G. Conversações. Rio de janeiro: Editora 34, 1992 (b). p. 219-226.

DELEUZE, G. Foucault. São Paulo: Brasiliense, 2005.

DREYFUS, H.; RABINOW, P. Michel Foucault, uma trajetória filosófica: para além do estruturalismo e da hermenêutica. Rio de Janeiro: Forense Universitária, 1995.

FOUCAULT, M. Microfísica do Poder. Rio de Janeiro: Graal, 1979.

História da Sexualidade I: a vontade de saber. Rio de Janeiro: Graal, 1988.

. Ordem do discurso. São Paulo: Loyola, 2004.

. Arqueologia do saber. Rio de Janeiro: Forense, 2009.

VEYNE, P. Foucault revoluciona a história. In: Como se escreve a história. Brasília: UNB, 1998. 